\title{
POLSKA KONSTYTUCJA Z 1997 ROKU JAKO ELEMENT EUROPEJSKIEGO DZIEDZICTWA KONSTYTUCYJNEGO
}

W kontekście toczących się obecnie sporów o Konstytucję, podważania jej roli, przypisywania jej komunistycznej proweniencji i tym samym negowania jej wartości znajdujemy się w sytuacji, kiedy pewne fakty z nie tak odległej historii powstawania tej Konstytucji trzeba stale przypominać, wręcz powtarzać pewne, wydawałoby się, oczywiste fakty dotyczące jej genezy i treści.

Dynamika przemian rzeczywistości społecznej i politycznej w początkowym okresie transformacji wymuszała konkretne „działania” konstytucyjne, a dyskusja intelektualna wobec tych działań była jakby wtórna. Ówczesna nowa sytuacja stawiała wiele znaków zapytania. Zniknęły tematy tabu, które ograniczały debatę konstytucyjną. Każde pytanie było dozwolone i uzasadnione. Nie było pytań zakazanych i nie było też gotowych, z góry zaplanowanych, „jedynie słusznych” odpowiedzi. Powstawały natomiast spory o model, konkretnych rozwiązań konstytucyjnych. Nowa konstytucja powstawała, tworzyła się w pewnym procesie ciagłym na gruzach rozbitego monolitu konstytucyjnego okresu realnego socjalizmu, a odpowiedzi, jak ma ona wyglądać, jakie wartości chronić, jaki przybrać kształt ustrojowy, było wiele ${ }^{1}$. Konieczne było znalezienie wyraźnego punktu odniesienia.

Jednym z takich było pytanie dotyczące odniesień do polskiej tradycji konstytucyjnej. Nie ulegało wątpliwości, że ta tradycja jest głęboka, sięga bowiem Konstytucji 3 maja z 1791 r., pierwszej konstytucji na kontynencie europejskim. Jednakże poza tą ponadpartyjną ogólną zgodą uznającą znaczenie tej konstytucji, znacznie trudniej było uzyskać zgodę, znaleźć jednoznaczną odpowiedź, do jakich konkretnych rozwiązań ustrojowych z naszej tradycji konstytucyjnej chcieliśmy nawiązywać. Część ugrupowań politycznych dążyła do nawiązania do Konstytucji marcowej, a część, co było wyraźnie widać w pracach komisji konstytucyjnej Senatu, poszukiwała odniesień do tradycji Konstytucji kwietniowej. Te odniesienia nie miały tylko wymiaru historycznego. Ich konsekwencją była inna wizja porządku ustrojowego państwa. Trudno było, zwłaszcza w pierwszym okresie tzw. Sejmu Okragłostołowego znaleźć wspólne stanowisko dotyczące konkretnych rozwiązań ustrojowych. To też m.in. powodowało, że proces przygotowywania konstytucji się przedłużał. Można było nawet usłyszeć opinię, że przeoczyliśmy „nasz moment konstytucyjny”.

${ }^{1}$ Por. R. Chruściak, W. Osiatyński, Tworzenie konstytucji w Polsce w latach 1989-1997, Warszawa 2001. 
W jakimś sensie podobna sytuacja istniała w innych państwach naszego regionu, dlatego też znaleźć można w literaturze konstatację, że kraje Europy Centralnej „have embarked on a process of trial and error in the making of new constitutions"2. Nasza polska dyskusja skoncentrowana była bardziej na podkreślaniu różnic aniżeli tego, co nas łączy w kontekście tradycji ustrojowej. Ten sposób myślenia jest niezwykle ważny także w naszej obecnej debacie o konstytucji nacechowanej wyraźnymi elementami konfrontacyjnymi.

Warto w tym kontekście odwołać się do opinii włoskiego prawnika Giovaniego M. Flicka, który wskazywał na wręcz odmienną postawę w podejściu do włoskiej konstytucji. Autor poszukuje w tradycji europejskiej tego, co łączy, a nie tego, co dzieli. Nie przeciwstawia chrześcijaństwa państwu świeckiemu, wskazując, że: „Wprawdzie pomiędzy chrześcijańskimi i świeckimi korzeniami Europy dochodzi do pewnego rodzaju starcia czy też konfrontacji, niemniej jednak przede wszystkim dochodzi do wzajemnego uzupełniania się wynikających z nich wartości, co pozwala przezwyciężyć cały szereg problemów spowodowanych konfrontacją"

Jedna z zasadniczych dyskusji na początkowym etapie prac nad konstytucją była dyskusja dotycząca aksjologii przyszłej konstytucji, przybierajaca niejednokrotnie formę sporu o wartości ${ }^{4}$, a jednym z jej elementów były problemy dotyczące zależności ius i lex. Zgodzić się należy z tym, że w państwach wychodzących z totalitaryzmu można było zaobserwować swoistą „rewitalizację" prawa naturalnego. Było tak w okresie postfaszystowskim i podobnie w okresie postkomunistycznym. Stało się oczywiste, że nie wystarczało samo podejście zasadzające się na pozytywizmie prawniczym. Wspólną tendencja stało się poszukiwanie odniesień do wartości istniejacych poza prawem pozytywnym, ale stanowiącym podstawę prawa stanowionego. Poszukiwania te w swej postaci prawniczej sprowadzały się właśnie do określenia zależności ius i lex $x^{5}$.

W tym myśleniu zakorzeniona jest też różnica pomiędzy stricte praworządnością formalną a rządami prawa (rule of law), odwołującymi się do wartości poza prawem stanowionym. I to w takim kontekście poszukiwano i odwoływano się do europejskiego dziedzictwa prawnego. Nie ulegało wątpliwości, że prawo jest integralnie związane z takimi pojęciami, jak tożsamość europejska, wspólne dziedzictwo europejskie, chrześcijańskie korzenie europejskie, wspólnota europejska.

Głównym zatem wyzwaniem dla wszystkich państw postsocjalistycznych stała się potrzeba „odkodowania”, przybliżania pojęcia „wspólne dziedzictwo prawne", choć proces ten napotykał i nadal napotyka wiele trudności zwią-

2 A.E. Dick Howard, Constitutional Reform, w: R.F. Staar (ed.), Transition to Democracy in Poland, New York 1993, s. 107.

${ }^{3}$ G.M. Flick, Elogio della Costituzione, Milano 2017.

${ }^{4}$ H. Suchocka, Spór o wartości w polskiej rzeczywistości ostatniej dekady, w: J. Barcz (red.), Prawda i pojednanie, $w 80$ rocznice urodzin W. Bartoszewskiego, Warszawa 2002, s. 227-237.

${ }^{5}$ P. Haberle, Ius et lex als Problem des Verfassungsstaates - das Beispiel der Verfassunggebung in Polen, w: M. Piechowiak, R. Hliwa (eds), The Draft Polish Constitution in the Light of Comparative Law, Poznań 1993, s. 58-63; a także: W. Łączkowski, Konstytucja a transformacja ustrojowa, w: Konstytucja i transformacja, Warszawa 1995, s. 9-10. 
zanych z precyzyjnym dookreśleniem elementów, jakie się na to dziedzictwo składają ${ }^{6}$. Nie ulega wątpliwości, że ważnym źródłem dla „odkodowywania” tego, co składa się na europejskie dziedzictwo prawne, były także dokumenty papieży dotyczące chrześcijańskiej nauki społecznej, począwszy od encykliki Leona XIII Rerum novarum z $1891 \mathrm{r.}^{7}$

Te podejmowane wówczas wysiłki w polskim procesie konstytucyjnym, ale także w innych państwach dostrzegane były przez Jana Pawła II. Stąd też tak ważne znaczenie miała jego encyklika Centesimus annus wydana w 1991 r., właśnie w stulecie encykliki Rerum novarum, które zbiegło się z początkiem procesu transformacji. Słowa w niej zawarte stanowić miały także wskazówkę, swoisty odnośnik do wartości stanowiących wspólne dziedzictwo konstytucyjne. Odwołując się do encykliki Rerum novarum, Jan Paweł II przypomina, że już Leon XIII przedstawił organizację społeczeństwa opartą na trzech władzach - prawodawczej, wykonawczej i sądowniczej. I dodaje: „Ten porządek odzwierciedla realistyczną wizję społecznej natury człowieka, która wymaga odpowiedniego prawodawstwa dla ochrony wolności wszystkich. Dlatego jest wskazane, by każda władza była równoważona przez inne władze i inne zakresy kompetencji, które by ją utrzymywały we właściwych granicach. Na tym właśnie polega zasada państwa praworządnego, w którym najwyższą władzę ma prawo, a nie samowola ludzi"8.

Odkrywanie elementów składających się na pojęcie wspólnego dziedzictwa konstytucyjnego stało się swoistym mitem założycielskim w nowych demokracjach Europy Środkowej. W tym kontekście niezwykle ważną rolę odgrywała Komisja Wenecka, utworzona w 1990 r., która pomagała państwom odkrywać to, co wyrastając ze wspólnej europejskiej tradycji prawnej, stawało się europejskim standardem, a więc wzorcem dla podejmowanych konkretnych rozwiązań prawnych. W sferze zatem kategorii ogólnej tzw. standard europejski postrzegany był jako wartość centralna. Stąd odwoływanie się do niego było ważnym weryfikatorem $\mathrm{w}$ procesie dokonywania zmian $\mathrm{w}$ wewnętrznym systemie prawnym, a zwłaszcza w procesie zmian konstytucji.

W kontekście odwoływania się do dziedzictwa europejskiego warto w tym miejscu przywołać wygłoszone znacznie później, ale jednak o wielkiej doniosłości, przemówienie Benedykta XVI w Bundestagu we wrześniu 2011 r., kiedy to, co bardzo znamienne, całe swoje wystapienie poświęcił prawu. Zostało ono zatytułowane „Refleksje na temat podstaw prawa”. Powiedział wówczas m.in.: „był to swoisty fenomen, kiedy w pierwszej połowie II stulecia przedchrześcijańskiego doszło do spotkania między rozwiniętym przez filozofów stoickich społecznym prawem naturalnym a wpływowymi nauczycielami prawa rzymskiego. $\mathrm{Z}$ tego kontaktu narodziła się zachodnia kultura prawna, która miała i do dzisiaj ma decydujące znaczenie dla kultury prawnej ludzkości. Z tej przedchrześcijańskiej więzi między prawem a filozofią wywo-

\footnotetext{
${ }^{6}$ A. Pizzorusso, Europejskie dziedzictwo konstytucyjne, Warszawa 2013.

7 Encyklika Rerum novarum, <www.nonpossumus.pl>.

8 Encyklika Centesimus annus, s. 44, <https://opoka.org.pl>centesimus_1>.
} 
dzi się droga, prowadząca - przez chrześcijańskie średniowiecze do rozwoju prawnego okresu oświecenia aż do Deklaracji Praw Człowieka [...]”9.

W poczuciu międzynarodowej odpowiedzialności papieża Benedykt dzieli się myślami dotyczącymi, jak sam to określa, „podstaw demokratycznego państwa prawa”. Jako reprezentujacy podmiot międzynarodowy, jakim jest Stolica Apostolska, rozważań swoich nie ogranicza do kontekstu jednego państwa, mimo że wygłasza je w konkretnym państwie, w konkretnym parlamencie. Nadaje swojemu wystapieniu charakter znacznie szerszej refleksji, wykraczającej poza prawo wewnętrzne państwa, osadza je głęboko w kontekście europejskim.

Refleksje swoje odnosi do prawa, które ukształtowało się w Europie, które kształtowało Europę i samo się wraz z tą Europą rozwijało i które tym samym jest istotnym czynnikiem tożsamościowym Europy. Trzy są zatem kluczowe elementy wizji prawa jako czynnika tożsamościowego Europy według Benedykta, a mianowicie:

1) spotkanie wiary, rozumu i prawa,

2) uznanie nienaruszalnej godności każdego człowieka, będącej podstawą praw i wolności człowieka,

3) obrona tak rozumianego prawa przez nas wszystkich, mieszkańców Europy.

Mimo że słowa Benedykta są późniejsze niż początek prac nad naszą konstytucja, to nie ulega wątpliwości, że takie właśnie myślenie o korzeniach europejskich nowej polskiej konstytucji towarzyszyło jej twórcom. Sięgali do dziedzictwa europejskiego, które zarazem było naszym wspólnym dziedzictwem. Nasza polska tradycja konstytucyjna nie tworzyła się w próżni. Wynikała ona z przynależności do Europy, z przynależności do wspólnego kręgu wartości.

Jednym z pierwszych kroków zmierzających do powrotu do tych wspólnych wartości była konieczność zerwanie z dualistyczną koncepcją prawa w wersji socjalistycznej. Ona odgradzała nas w istotny sposób od dziedzictwa europejskiego. Przejawem najbardziej wyrazistym tej koncepcji było m.in. orzeczenie Sądu Najwyższego PRL z 1987 r. ${ }^{10}$ W orzeczeniu tym SN wyraźnie nakreślił linię, że prawo międzynarodowe nie może obowiązywać w porządku krajowym ex proprio vigore. Dopóki normy prawa międzynarodowego nie zostaną w sposób przewidziany prawem wewnętrznym wprowadzone do tego prawa, takim prawem nie stają się, a w konsekwencji nie wiążą sądów.

${ }^{9}$ Przemówienie papieża Benedykta XVI, <www.vatican.va>.

10 SN (dokładnie Izba Pracy i Ubezpieczeń Społecznych) w swoim orzeczeniu z 25 sierpnia 1987 r. stwierdził, że „w świetle przepisów naszej konstytucji [PRL] brak podstaw do uznania, iż z chwilą ratyfikacji następuje transformacja norm prawa międzynarodowego do prawa wewnętrznego [...]. Jest to jedynie zobowiązanie się państwa do wprowadzenia ratyfikowanych norm prawa międzynarodowego do prawa wewnętrznego". Por. szerzej: L. Kański, Konstytucyjna regulacja statusu jednostki a międzynarodowa ochrona praw człowieka, w: Z. Kędzia (red.), Prawa, wolności i obowiazki człowieka i obywatela $w$ nowej polskiej konstytucji, Poznań 1990, s. 85, a także H. Suchocka, The constitutional trends in Central and Eastern Europe, „Polish Western Affairs” 1992, nr 1, s. 24-43. 
Cel takiej konstrukcji w ówczesnych warunkach był oczywisty. Tylko bowiem taka koncepcja, stricte dualistyczna, umożliwiała m.in. blokowanie prawa do wolności stowarzyszenia, w tym wolności związkowej, wynikającej z podpisanych i ratyfikowanych przez Polskę umów międzynarodowych, jakimi były np. Pakty Praw Człowieka.

Koncepcja ta zarazem stwarzała podstawy możliwości swobodnego uznania przez władze, jakie prawa będą w prawie krajowym gwarantowane, a jakie nie, mimo ratyfikowanych traktatów. Oczywiście w takich warunkach nie było żadnej możliwości podjęcia nawet dyskusji o europejskim standardzie prawnym, a europejskie dziedzictwo prawne nie mogło stanowić punktu odniesienia.

Stąd też jednym z celów, nie tylko w Polsce, ale we wszystkich państwach, które aspirowały do „powrotu do Europy”, niezależnie jak szeroko i rozmaicie rozumiano to pojęcie powrotu, było dążenie do przełamania rygorystycznego dualizmu dwóch porządków prawnych, międzynarodowego i krajowego.

Zmiana zasady dualizmu obu porządków prawnych i nowe podejście do relacji pomiędzy prawem międzynarodowym a prawem wewnętrznym wynikały z kilku przyczyn:

1) politycznej - każde z tych państw chciało zaznaczyć swoją otwartość, podkreślić wychodzenie $\mathrm{z}$ izolacji dotychczasowego systemu politycznego i prawnego, a zmiana podejścia do prawa międzynarodowego była tego niewatpliwym dowodem;

2) ideowej - wszystkie te państwa zamierzały stać się członkami zorganizowanej struktury europejskiej, jaką była Rada Europy, która postrzegana była jako instytucja będąca nośnikiem uniwersalnych wartości związanych z państwem prawa i gwarancja praw i wolności człowieka opartych na centralnej wartości, jaką jest godność osoby ludzkiej.

3) pragmatycznej - wiążącej się integralnie z poprzednia, a polegającej na tym, że wszystkie te państwa chciały przystapić do Konwencji o ochronie praw człowieka i podstawowych wolności (EKPC). To zaś wymagało zagwarantowania obywatelom poszczególnych państw możliwości przekroczenia granic własnego państwa $\mathrm{w}$ dochodzeniu swoich praw przed organem międzynarodowym, jakim był Europejski Trybunał Praw Człowiek (ETPC). Zasada dualizmu zaś w pełni to blokowała i oddzielała nas od dziedzictwa prawnego Europy.

Przyjęcie koncepcji monizmu pozwalało zatem zmienić tę sytuację i otworzyć możliwość odwoływania się do wzorca istniejącego w prawie ponadkrajowym, wywodzącego się z tradycji europejskiej. Celem zaś było dążenie do stworzenia swoistej homogeniczności rozwiązań w prawie wewnętrznym państwa z systemem europejskim, w którym zasadę godności człowieka jako zakotwiczoną w prawie naturalnym uznano za główny punkt odniesienia.

Te wszystkie związki tak ważne dla wspólnego dziedzictwa europejskiego zostały poprzecinane w okresie komunizmu. Państwa Europy Centralnej i Wschodniej, w tym Polska, poddane zostały innemu eksperymentowi prawnemu, silnemu centralizmowi, opartemu na ograniczeniu wolności osobistej, i sprowadzeniu jej do wolności wyznaczanej przez władzę państwową. 
Konieczne stało się także przywrócenie właściwego znaczenia pojęciom zdeformowanym w poprzednim systemie, w którym pod identycznymi nazwami kryło się zupełnie inne ich rozumienie, np. zasada demokracji, państwa prawa czy niezależności sądów i niezawisłości sędziów. I w tym zakresie odwoływanie się do zastanych pojęć zaliczanych do dziedzictwa europejskiego było niezwykle ważne ${ }^{11}$.

Rozwiąania w nowej konstytucji dotyczące zasad ustrojowych chciano zatem oprzeć na antytezie zasad, które obowiązywały w poprzednim ustroju i niewątpliwie taka była wspólna zgoda wszystkich ówczesnych sił politycznych w toku prac w komisji konstytucyjnej. Zatem: pluralizm zamiast kierowniczej roli partii, zasada podziału władz zamiast jedności władzy, autonomia sądownictwa zamiast powiązań z władzą wykonawczą i dominującą rolą ministra sprawiedliwości w obrębie władzy sądowniczej. Istniała zgoda co do tego, że zasady odwołujące się do tamtej, minionej „aksjologii” nie mogły pretendować do bycia elementem europejskiego dziedzictwa prawnego.

W tym miejscu uczynić należy uwagę, która jest często podnoszona w obecnym sporze o konstytucję dotyczącym respektowania zasad państwa prawa. W kontekście odniesień do dziedzictwa europejskiego pojawia się problem dotyczacy zakresu suwerenności państwa i związanej z tą zasadą swobody oceny dokonywanej przez poszczególne państwa i podejmowanych w tym kontekście rozstrzygnięć. Można zauważyć, że odwoływanie się do dziedzictwa prawnego Europy w obszarze bardzo ogólnych idei czy haseł jest do jakiegoś stopnia akceptowane. Problem pojawia się w momencie odwoływania się do konieczności przestrzegania konkretnych zasad leżących u podstaw państwa prawa, wynikajacych z traktatów międzynarodowych, będących także wyrazem tego wspólnego dziedzictwa. Wówczas to pojawia się argument o władzy suwerennej państwa i swobodzie w zakresie decydowania o podejmowanych rozwiązaniach prawnych. Podważany jest, wydawałoby się oczywisty, pogląd, że jeśli państwo suwerenne samo wiąże się traktatami, to nie traci swojej suwerenności, ale w istocie swojej wykonuje swoją suwerenność, realizując także zobowiązania wynikające z traktatów. Ta teza jak najbardziej uzasadniona, zdaje się, że nie wszystkich przekonuje ${ }^{12}$.

W tym kontekście wydaje się uzasadnione wyraźne rozróżnienie dwóch materii. W istocie bowiem w procesie tworzenia nowej konstytucji, zwłaszcza

${ }^{11}$ O znaczeniu tego problemu świadczy fakt zorganizowania w $1996 \mathrm{r}$. specjalnej konferencji w Montpellier na temat Europejskiego dziedzictwa konstytucyjnego. Por. Le patrimoine constitutionnel europeen, Editions du Conseil de l'Europe, Strasbourg 1997.

${ }^{12} \mathrm{~W}$ tym kontekście zatem warto odwołać się do innego autorytetu, którym jest Edyta Stein, ogłoszona przez Jana Pawła II współpatronką Europy w roku 1999. Ciekawe są zwłaszcza jej rozważania dotyczące tworzenia struktur ponadnarodowych. Już w listach do Ingardena zwracała uwagę na tworzenie wspólnoty kulturowej ponad granicami państw. W tym sensie była Europejka. Myślę, że jej wizja została trafnie ujęta w motu proprio Jana Pawła II w słowach: „wznieść nad starym kontynentem sztandar szacunku, tolerancji i otwartości, wzywający wszystkich ludzi, aby się wzajemnie rozumieli i akceptowali, niezależnie od różnic etnicznych, kulturowych i religijnych" (Jan Paweł II, List Apostolski Motu Proprio, 1 października 1999 r. ogłaszający św. Brygide Szwedzka, św. Katarzynę ze Sieny i św. Teresę Benedyktę od Krzyża Wspótpatronkami Europy, s. $9,<w w w . o p o k a . o r g . p l>$. 
w zakresie ochrony praw człowieka osadzonej na przyrodzonej godności człowieka, występują dwie tendencje. Pierwsza, wydaje się dominująca, zmierza do tworzenia i chronienia standardów wyrastających ze wspólnego dziedzictwa w przestrzeni europejskiej. Druga dotyczyła tego, w jakiej mierze w ramach tej ogólnej tendencji istnieje możliwość zachowania pewnych odrębności krajowych $^{13}$.

Niezależnie od poszukiwań wspólnych rozwiązań zgodnych ze standardami europejskimi, ważna tendencja nowego procesu konstytucyjnego stało się, jak wspomniałam w innym miejscu, odwoływanie do własnej tradycji wszędzie tam, gdzie to było możliwe. Wyraźnym tego przykładem są słowa ze Wstępu do polskiej konstytucji: „wdzięczni naszym przodkom za ich pracę [...] za kulturę zakorzenioną w chrześcijańskim dziedzictwie Narodu i ogólnoludzkich wartościach, nawiązujac do najlepszych tradycji Pierwszej i Drugiej Rzeczypospolitej"14. Jak podkreśla się w literaturze, w odniesieniu do powstawania konstytucji termin „tradycja” należy wiązać z problematyką ustrojowa, a więc z tradycją ustrojową Polski ${ }^{15}$.

Dla celów poszukiwania odpowiedzi na pytanie dotyczące możliwości zachowania pewnych odrębności krajowych konieczne jest zatem wyraźne rozróżnienie dwóch materii, a mianowicie:

1) tego, co stanowi fundament europejskiej tradycji demokratycznej, europejskiego dziedzictwa prawnego i co musi być bezwzględnie respektowane przez państwa członkowskie,

2) tego, co należy do swobody regulacyjnej poszczególnych państw, wynikającej z ich zróżnicowanej i bogatej tradycji ustrojowej ${ }^{16}$.

Mogłoby się wydawać, że obie te tendencje są sprzeczne, ale tak rzecz się ma tylko z pozoru. W istocie bowiem są to procesy wzajemnie się uzupełniajace. Najogólniej można by stwierdzić, że część pierwsza odnosi się do zasad, a część druga - do konkretnych form ich realizacji.

Nie ulega wątpliwości, że system europejski (zwłaszcza system Rady Europy) dopuszcza współistnienie wspólnych standardów podstawowych i krajowych swoistości. Kluczową w tym zakresie jest zasada subsydiarności. Europejski Trybunał Praw Człowieka wypracował w tym zakresie określone narzędzia jeszcze w epoce przed zasadniczym poszerzeniem, zasadzajace się właśnie na zasadzie subsydiarności. Ważna, choć kontrowersyjna, stała się tutaj koncepcja marginesu uznania - margin of appreciation, która stwarza pewną elastyczność niezbędną dla uniknięcia niszczącej konfrontacji pomiędzy ETPC a państwami członkowskimi i pozwala sądowi zapewnić równowagę pomiędzy suwerennością państw członków a ich zobowiązaniami

${ }^{13}$ H. Suchocka, Potransformacyjny proces zmian konstytucji w państwach Europy Środkowej $i$ Wschodniej $w$ świetle doświadczeń Komisji Weneckiej, w: J. Ciapała, P. Mijal (red.), Wokót wybranych problemów konstytucjonalizmu, Księga Jubileuszowa profesora Andrzeja Bałabana, Warszawa 2017, s. 311-313.

${ }^{14}$ Konstytucja Rzeczypospolitej Polskiej, Wstęp, Warszawa 1997.

${ }_{15}$ M. Piechowiak, Komentarz do Preambuty Konstytucji RP, w: M. Safjan, L. Bosek (red.), Konstytucja RP, t. 1, Warszawa 2016, s. 141.

${ }^{16}$ To rozróżnienie jest zawsze podkreślane w opiniach Komisji Weneckiej, por. np. Opinia o nowej konstytucji wegierskiej, CDL(2011)016. 
wynikającymi z $\mathrm{EKPC}^{17}$. Ma to zostawić państwom pewna przestrzeń do manewru prawnego, jednakże nie poza, ale w ramach EKPC. Także Traktat UE w art. 6 ust. 2 przywołuje „wspólne tradycje konstytucyjne krajów członkowskich” („Unia respektuje podstawowe prawa zagwarantowane w $\mathrm{EKPCz}$ [...] i prawa wynikające z tradycji konstytucyjnych wspólnych dla państw członkowskich").

W tym kontekście kluczowe jest jednak dookreślenie, co należy do tych niepodważalnych gwarancji podstawowych. Bez watpienia należy do nich zasada rule of law, demokratycznego państwa prawa. Jej istotnym elementem jest podział władz, autonomia sądów i niezawisłość sędziów. Nacisk egzekutywy na sądy zawsze w myśleniu europejskim był traktowany jako patologia.

Nasuwa się w tym miejscu kolejne ważkie pytanie, a mianowicie: czy kontrola konstytucyjności prawa należy do tych gwarancji podstawowych i czy stanowi ona element wspólnego dziedzictwa konstytucyjnego?

Zapewne mogą pojawić się wątpliwości dotyczące długości istnienia jakiejś instytucji, aby mogła ona być uznana za element dziedzictwa prawnego. Sadzę jednak, że decydować o tym mogą też inne cechy, a zwłaszcza znaczenie takiej instytucji dla realizacji kluczowej zasady, jaką jest rule of law. W takim rozumieniu kontrola konstytucyjności prawa, mimo że jest stosunkowo nowa instytucja $\mathrm{w}$ europejskim dorobku konstytucyjnym, stanowi istotny element europejskiego dziedzictwa prawnego ${ }^{18}$.

Doświadczenie Europy Zachodniej pokazuje, że sukces demokracji związany jest $\mathrm{z}$ istnieniem kontroli konstytucyjności prawa. Pozwala ona zapewnić supremację prawa nad polityka ${ }^{19}$. Ten rodzaj instytucji stwarza nową sferę równowagi, która oznacza, że nawet parlament jako ustawodawca może być poddany kontroli w zakresie prawa ${ }^{20}$. Konkretny model nie jest $\mathrm{w}$ tym przypadku istotny. Istotna jest autonomia i niezależność organu, spełniającego taka kontrolę ${ }^{21}$.

Trybunał Konstytucyjny w wielu sytuacjach stawał się ważnym instrumentem dynamicznej interpretacji konstytucji (np. prawa do sądu w Polsce). Polski Trybunał Konstytucyjny wypowiedział się w 1994 r., a więc w trakcie prac nad konstytucja, w sprawie klauzuli o wartościach chrześcijańskich w aktach prawnych, postrzegając sformułowanie o wartościach chrześcijańskich nie w kategoriach religijnych, lecz jako wyraz uniwersalnych kategorii etycznych kultury śródziemnomorskiej, które nie powinny być negowane. Działal-

${ }^{17}$ Szerzej: A. Wiśniewski, Koncepcja marginesu oceny w orzecznictwie Europejskiego Trybunału Praw Człowieka, Gdańsk 2008.

${ }^{18}$ CDL-AD (2013)014, Opinion on the Draft Law on the amendments to the Constitution, Strengthening the Independence of Judges (including an explanatory note and a comparative table) and on the Changes to the Constitution proposed by the Constitutional Assembly of Ukraine, para. 76.

${ }^{19}$ S. Ruelke, Venedig-Kommission und Verfassungsgerichtsbarkeit, Georg-August-Universitaet Goettingen, Institut fuer Voelkerrecht, Dissertation, s. 104-107.

${ }^{20}$ J. Zakrzewska, Spór o konstytucje, Warszawa 1993.

${ }^{21}$ H. Suchocka, Stanowisko Komisji Weneckiej dotyczace pozycji ustrojowej sadownictwa konstytucyjnego w demokratycznym państwie prawa, „Ruch Prawniczy, Ekonomiczny i Socjologiczny” 78, 2016 , z. 1 , s. $5-18$. 
ność orzecznicza Trybunału Konstytucyjnego miała dla kraju, który dopiero kształtował swój ustrój demokratyczny i ciągle borykał się z dziedzictwem systemu monoideologicznego, szczególne znaczenie, gdyż przyczyniała się do współtworzenia kultury prawnej i politycznej w sytuacjach niedookreślenia jeszcze bardzo wielu obszarów życia publicznego.

Można zatem powtórzyć pytanie, gdzie jest ta granica swobody państw, gdzie jest ta nieprzekraczalna bariera niezmienialnego, co stanowi niepodważalny standard europejski. Zgadzając się bowiem na to, że państwa korzystaja z marginesu uznania $\mathrm{w}$ kwestii odmiennej regulacji pewnych materii w prawie wewnętrznym, równocześnie uznać trzeba, że istnieją zasady mające charakter aksjomatu zakorzenionego w europejskiej tradycji prawnej i te muszą być bezwzględnie przestrzegane. One to bowiem tworzą system, szkielet, albo nawet wyraźniej - ścianę nośną całej konstrukcji prawnej. Tylko na tym jednolitym, stabilnym „rusztowaniu” można budować zróżnicowane rozwiązania szczegółowe, uwzględniające różne tradycje kulturowe i zapewnić im gwarancje ochrony. Niezależnie od różnic występujących u podstaw dwóch tradycji (porządków) prawnych, jakie istnieją w Europie, tj. zarówno systemu kontynentalnego, jak i anglosaskiego, możliwe było znalezienie wspólnego kośćca, wspólnego fundamentu zakotwiczonego w europejskich wartościach prawnych, które pozwalały na wykształcenie pojęcia, jakim jest europejski standard prawny.

Poszukiwanie zatem odrębności rozwiązań jest dość ograniczone aksjomatem wynikającym ze wspólnego rozumienia dziedzictwa konstytucyjnego. Został on bardzo wyraźnie wyrażony przez Loewensteina, że: „Historia konstytucjonalizmu nie jest niczym innym jak poszukiwaniem przez człowieka politycznego granic absolutnej władzy przez jej nosicieli i staraniem, aby w miejsce ślepego podporządkowania absolutyzmowi istniejącej zwierzchności ustanowić autorytet uzasadniony duchowo, moralnie i etycznie".

Podobna myśl została wyrażona wprost w wypowiedzi brytyjskiego premiera w zwiazku z obchodami rocznicy 800-lecia Magna Charta Libertatum. Powiedział on wówczas: „800 lat temu król Jan przyłożył pieczęć na dokumencie, który zmienił świat. [...] Nastapiło określenie granic władzy wykonawczej, zagwarantowanie dostępu do sądu, wiara, że istnieje coś takiego jak rule of law. Może się wydawać dzisiaj, że to były niewielkie rzeczy, ale miało to wówczas rewolucyjny wymiar, pozwoliło ukształtować równowagę władzy pomiędzy rządzacymi i rządzonymi".

Koncepcja rule of law stała się jedna z podstawowych zasad naszej Konstytucji z 1997 r., wyrażoną w art. 2 stwierdzającym, że: „Rzeczpospolita Polska jest demokratycznym państwem prawnym [...]". Konstytucja zbudowana na tej zasadzie powinna sprzyjać kształtowaniu w społeczeństwie postaw poczucia konstytucjonalizmu związanego z jej stabilnościa, a nie być traktowana tylko, zgodnie z tezą Carla Schmitta, jako instrument wyłącznie polityczny w sporze pomiędzy siłami politycznymi. Teza Schmitta, że: „Retoryka walki politycznej powoduje, że każda partia uczestnicząca w tej walce uznaje za prawdziwą tylko tę konstytucję, która odpowiada jej politycznym żądaniom. Jeżeli zasadnicze sprzeczności polityczne i społeczne są bardzo silne, łatwo może dojść do tego, że jakaś partia może każdej konstytucji, która nie spełnia 
jej żądań, w ogóle odmawiać tego miana" 22 , jest bardzo niebezpieczna. Prowadzić ona może w kierunku przeciwnym niż odwoływanie się do europejskiego dziedzictwa prawnego. Można mieć nadzieję, że nie pójdzie w tym kierunku nasza obecna „debata” konstytucyjna.

dr hab. Hanna Suchocka

Profesor Uniwersytetu im. Adama Mickiewicza w Poznaniu

hansuc@amu.edu.pl

\author{
THE POLISH CONSTITUTION OF 1997 AS PART \\ OF THE EUROPEAN CONSTITUTIONAL HERITAGE
}

Sum mary

The aim of this paper is to present axiological rsearches that were going on during the work on the Polish Constitution in the early years of transformation. One of the fundamental discussions at the initial stage of the work on the Constitution was a discussion that often took the form of a dispute about values. One of the elements of the dispute was the problem of dependence between ius and lex. In this context, references were made to the European legal heritage and concepts such as European identity or the common European legal heritage. The main challenge for all post-socialist countries was the need to 'decode', or explain the concept of 'common legal heritage'. This concept became a peculiar founding myth in the new democracies of Central Europe. In this context, the Venice Commission (formed in 1990) played an extremely important role by helping countries to discover what evolved from the common European legal tradition to become a European standard, and consequently, a model for concrete legal solutions. In the general category, therefore, the so-called European standard was perceived as a central value and a reference to it was an important verifier in the process of reviewing the internal legal system and, particularly, in the process of constitutional changes, especially on issues such as the rule of law, separation of powers, or the independence of the judiciary and judicial control over the constitutionality of the law. Despite disputes concerning specific political regulations, the consensus that prevailed was that the rules which referred to the 'axiology' of the previous system could not pretend to constitute an element of the European legal heritage and thus could not serve as a basis for the drafting of a new Polish Constitution.

${ }^{22}$ C. Schmitt, Nauka o konstytucji. Teologia polityczna, Warszawa 2013, s. 77. 